Available online at

http://journal.ugm.ac.id/jifnp
INDONESIAN FOOD AND NUTRITION PROCRESS

Indonesian Food and Nutrition Progress, 2017, Vol. 14, Issue 1

\title{
Pigment Production of Monascus sp. Isolated from Angkak in Semarang Region, Central Java, Indonesia
}

\author{
Soni Nugraha, Arina Tri Lunggani, Endang Kusdiyantini ${ }^{*}$ \\ ${ }^{1)}$ Department of Biology, Faculty of Sciences and Mathematics, Diponegoro University, Semarang, Indonesia \\ ${ }^{*}$ Corresponding author, email address: kusdiyantini@undip.ac.id
}

Received 21 Jan 2017; Accepted 12 May 2017; Published Online 15 May 2017

\begin{abstract}
Angkak (red fungi rice, red yeast rice) is a traditional fermentation by fungi Monascus in a lot of Asia Countries, which is useful as a natural food colorant. The aim of this research was to obtain pure isolate of red fungus from angkak in Semarang. The growth and the red pigment production of the selected isolate in the different initial medium $\mathrm{pH}$ and nitrogen sources were observed. The treatment was done by growing the isolate in PDB (Potato Dextrose Broth) medium at initial pH 3, 5, 7 and 9 and as well as optimization of nitrogen sources with $1 \%$ ammonium chloride, $1 \%$ ammonium nitrate, and $1 \%$ peptone. The results showed that the highest absorbance value of pigment (0.81) was obtained at $\mathrm{pH} \mathrm{7,} \mathrm{and} \mathrm{the} \mathrm{highest} \mathrm{value} \mathrm{of} \mathrm{the} \mathrm{cell} \mathrm{dry} \mathrm{weight} \mathrm{was} \mathrm{also}$ obtained at $\mathrm{pH} 7(1.23 \mathrm{~g} / \mathrm{L})$. The results showed that $1 \%$ ammonium chloride was the best nitrogen source for red pigment production which gives the highest absorbance (0.82) and the highest of dry weight (2.56 g/L) was obtained by using medium with $1 \%$ ammonium nitrate as a nitrogen source.
\end{abstract}

Keywords: pigment, angkak,isolate, fungi, $\mathrm{pH}$

\section{Introduction}

Pigment is a very important component for the consumer's appreciation especially for a food. Recently, the use of natural pigments is more acceptable to the consumers than synthetics pigment for industrial application because of its safety. Diversification of natural pigment sources will support the use of pigments that is safe for health and improves nutrients content of the product. One of the alternatives of natural carotenoids sources is a secondary product of microorganisms. Angkak is one of the pigments, which is useful in Asia countries, especially China, Japan, Philippine, Indonesia. The angkak is produced by fermentation of Monascus using the rice as a substrate.
The major pigments production of the Monascus consists of pairs of yellow (ankaflavin and monascin), orange (rubropunctatin and monascorubrin) and red (rubropunctamine and monascorubramine) compounds. The fungi are also useful in medicine production because of its monacolin $\mathrm{K}$ (lovastatin) compound that capable for lowering blood cholesterol (Panda et al., 2009). But, some researchers showed citrinin as a toxin compound producing by Monascus. Recently, the research is focused on the increasing of monacolin $\mathrm{K}$ and the decreasing of citrinin compound (Priatni et al., 2014). Mamucod et al., (2014) was also reported that the sold angkak in Nueva Ecija, Philippine was safe to consume, because the angkak contains 
antioxidants, phenolic compounds, mevinolin and low citrinin concentration.

Isolation of Monascus from the commercial product is still interesting research to find a hyperproducing of isolate (DurakhVelioğlu et al., 2013; Rashmi and Padmavathi, 2013). The aim of the research was isolation of Monascus from the local market in Semarang region and optimization of the growth and red pigment production at various initial $\mathrm{pH}$ medium and nitrogen sources.

\section{Materials and Methods}

\section{Isolation and Identification of Fungi}

Angkak was obtained from a local market in Semarang, Central Java, Indonesia. Isolation of fungi was carried out in petri dish containing Potato Dextrose Agar (PDA) media. The petri dish were incubated at $30^{\circ} \mathrm{C}$ for 7 days until the colonies were observed (Lee et al., 2010). Identification of isolate was performed based on morphological characteristics. Selected isolate was conserved at $4^{\circ} \mathrm{C}$ in PDA for further research.

\section{Inoculum}

Preparation of inoculum was conducted on petri dish containing PDA medium. The inoculum was incubated at $30^{\circ} \mathrm{C}$ for 7 days. Spores were put into the tubes to obtain spores suspension at the final of incubation. The number of spores $10^{7}$ spores $/ \mathrm{mL}$ was used as an inoculum for the growth of this isolate in various initial medium $\mathrm{pH}$ and nitrogen sources.

The growth of isolate selected at various initial medium $\mathrm{pH}$

About $1 \mathrm{~mL}$ of spores suspension was inoculated in $250 \mathrm{~mL}$ potato dextrose broth (PDB) medium at various initial medium $\mathrm{pH}$ (3, 5, 7, and 9). The culture was incubated at rotary shaker $120 \mathrm{rpm}$, room temperature for 14 days. The extracellular pigment and biomass were analyzed during the fermentation. The growth (biomass) was evaluated based on cells dry weight.

The growth of isolate selected at various nitrogen sources

About $1 \mathrm{~mL}$ of spores suspension was inoculated in $250 \mathrm{~mL}$ PDB medium at various nitrogen sources ( $1 \%$ ammonium chloride, $\mathrm{NH}_{4} \mathrm{Cl} ; 1 \%$ ammonium nitrate, $\mathrm{NH}_{4} \mathrm{NO}_{3}$ and $1 \%$ peptone). The medium $\mathrm{pH}$ was chosen from the optimum $\mathrm{pH}$ from previous research. The culture was incubated at rotary shaker 120 rpm, room temperature for 14 days. The extracellular pigment and biomass were analyzed at final of the fermentation. The growth (biomass) was evaluated based on cells dry weight by gravimetric methods. The red pigment production was analyzed by spectrophotometer at wavelength of $500 \mathrm{~nm}$.

\section{Statistical analysis}

The data were analyzed by single factor of Completely Randomized Design for $\mathrm{pH}(3,5$, 7 , and 9), and source of nitrogen (ammonium chloride, ammonium nitrate, and peptone). Each experiment was conducted in triplicate.

\section{Results and Discussion}

Isolation and Morphology Characteristics of Isolate from Angkak in Semarang

The isolation of fungi on PDA medium from 44 rice samples found nine purified isolates (Fig. 1). Based on the growth and the pigment production, the isolate number 2 was observed as the best isolate for further research. Fig. 2 shows colonies red isolate number 2 in agar slants. 


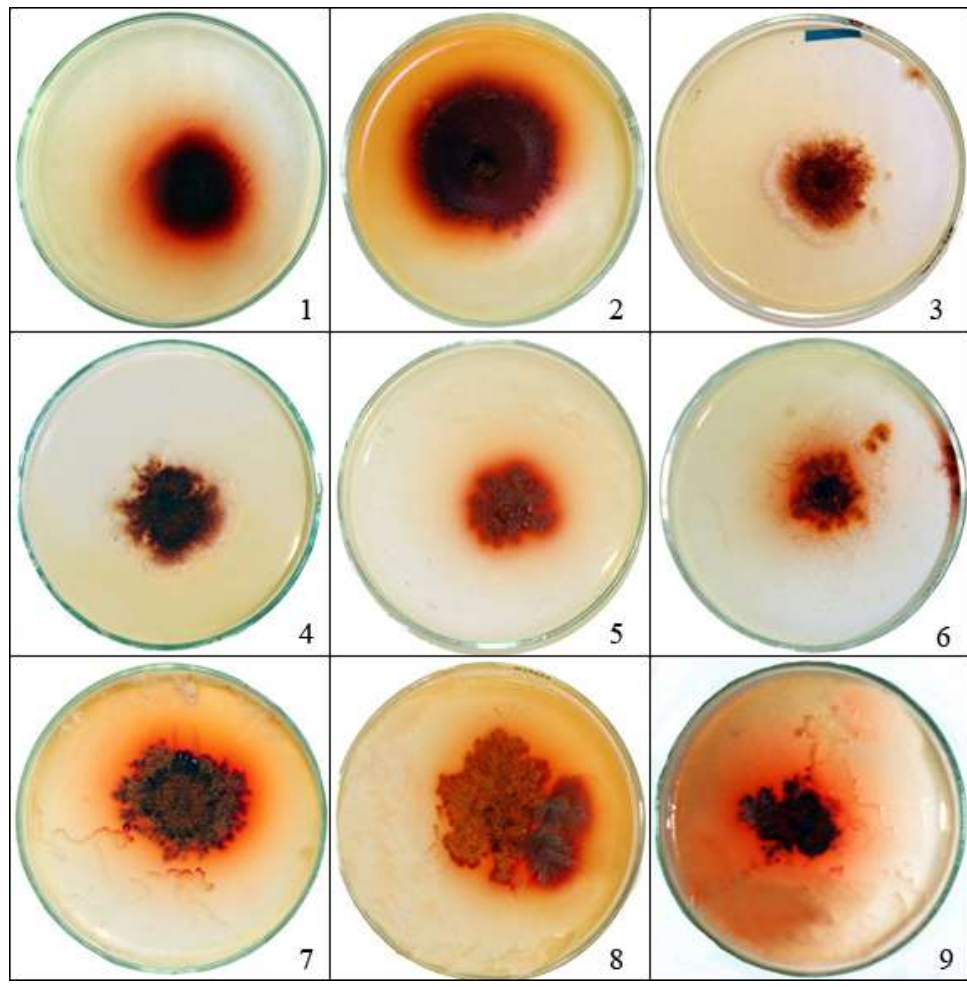

Fig. 1 Isolates of filamentous fungi of angkak in Semarang, incubation for 14 days

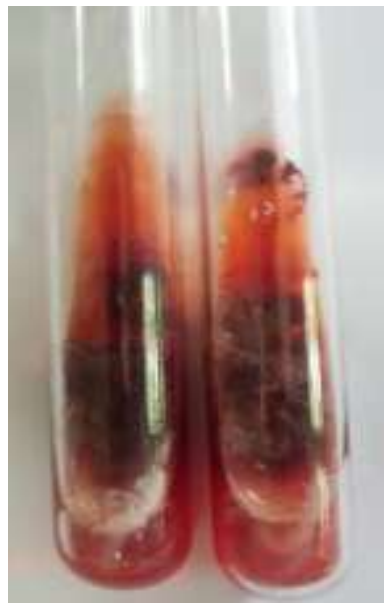

Fig. 2 Colonies red isolate number 2 in agar slants, incubation for 14 days.

The selected isolate was characterized by hypha, aleuroconodia, clestothecia, ascospore, and diameter of ascocarp was 20 $\mu \mathrm{m}$ (Fig. 3). Ungureanu (2012) stated that Monascus sp. possessed septa hypha, with hyaline wall of 3-5 $\mu \mathrm{m}$ in diameter. Sexual hypha has ascospore, which is covered with ascocarp and asexual hypha has conidiospore.
The rounded ascocarp has a yellowish color with 20-70 $\mu \mathrm{m}$ in diameter, oval ellipse shaped and hyaline wall 5-5×3-4 $\mu \mathrm{m}$. Asexual reproduction has a chain conidiospore, with thin wall conidiospore, functioning as a chlamydospore when the wall of the conidiospore is thickening. 

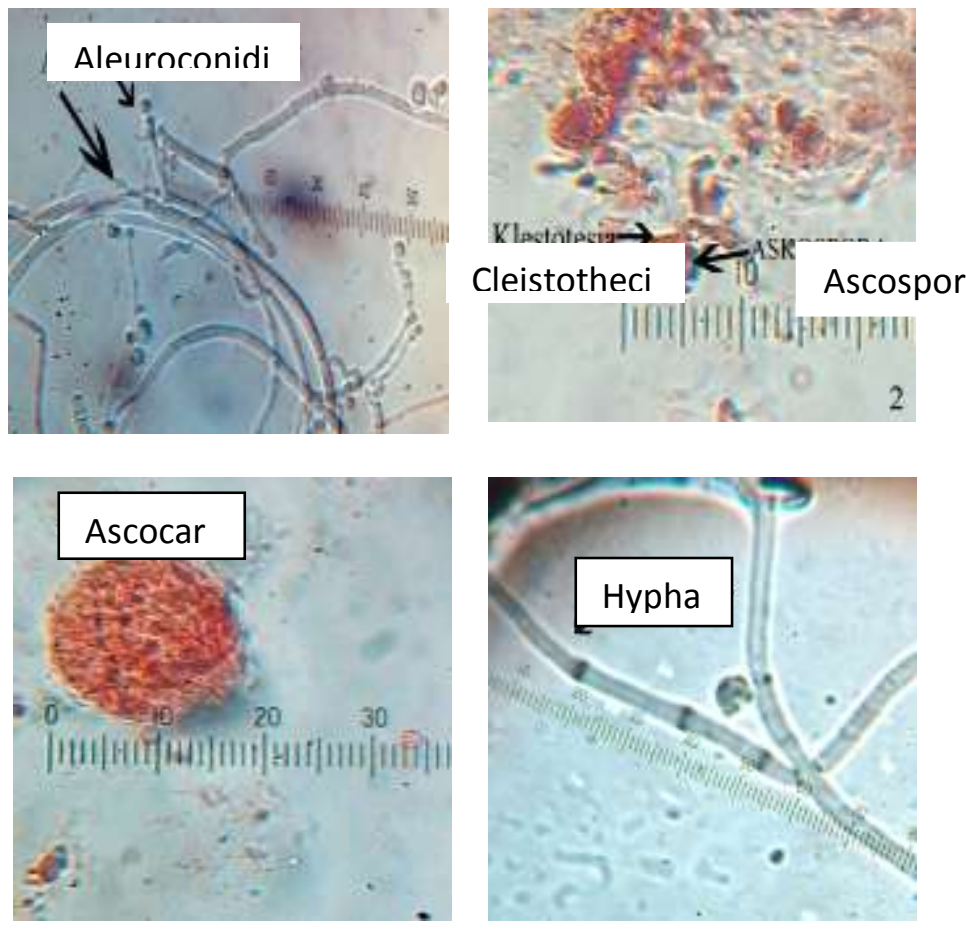

Fig. 3 Microscopic observation of isolate number 2.

\section{The Growth of Isolate Number 2 at Various Initial pH Media}

The highest average value of biomass dry weight was $1.23 \mathrm{~g} / \mathrm{L}$ at $\mathrm{pH} 7$, whereas the average of biomass was $0.31 \mathrm{~g} / \mathrm{L}$ and $0.48 \mathrm{~g} / \mathrm{L}$ at $\mathrm{pH} 3$ and 5 , respectively. The lowest average of biomass dry weight was $0.31 \mathrm{~g} / \mathrm{L}$ at $\mathrm{pH}$ 9. According to Kaur et al. (2009), the optimum $\mathrm{pH}$ condition for the growth of Monascus was between 5.5 and 7. The environment condition did not support the development of the cells at below or above the optimum $\mathrm{pH}$. The average of biomass dry weight at different pH is shown in Fig. 4.

The result of variance analysis $(p \leq 0.05)$ showed that difference $\mathrm{pH}$ did not affect the biomass dry weight of isolate number 2 , hence the Benferroni test was not performed. Based on the correlation test at the $\mathrm{pH}$ treatment, the average pigment production related significantly with the average of biomass dry weight cell.

\section{The growth of isolate number 2 at Various} Nitrogen Sources

The highest average value of cell dry weight was $2.56 \mathrm{~g} / \mathrm{L}$ by the addition of ammonium nitrate (Fig. 5). The use of ammonium chloride resulted in cell dry weight of $1.00 \mathrm{~g} / \mathrm{L}$. The lowest cell dry weight was $0.30 \mathrm{~g} / \mathrm{L}$ by the addition of peptone. Different source of nitrogens affected highly significant towards the cell dry weight of isolate number 2 $(p<0.05)$. Based on the correlation test on the treatment of different nitrogen source, the average level of pigment did not correlate significantly with the average of cell dry weight. Addition $1 \%$ of anorganic nitrogen, such as ammonium nitrate, supported the growth of Monascus and the production of pigment that was used as supplementation on Monascus fermentation (Babitha et al., 2007). 


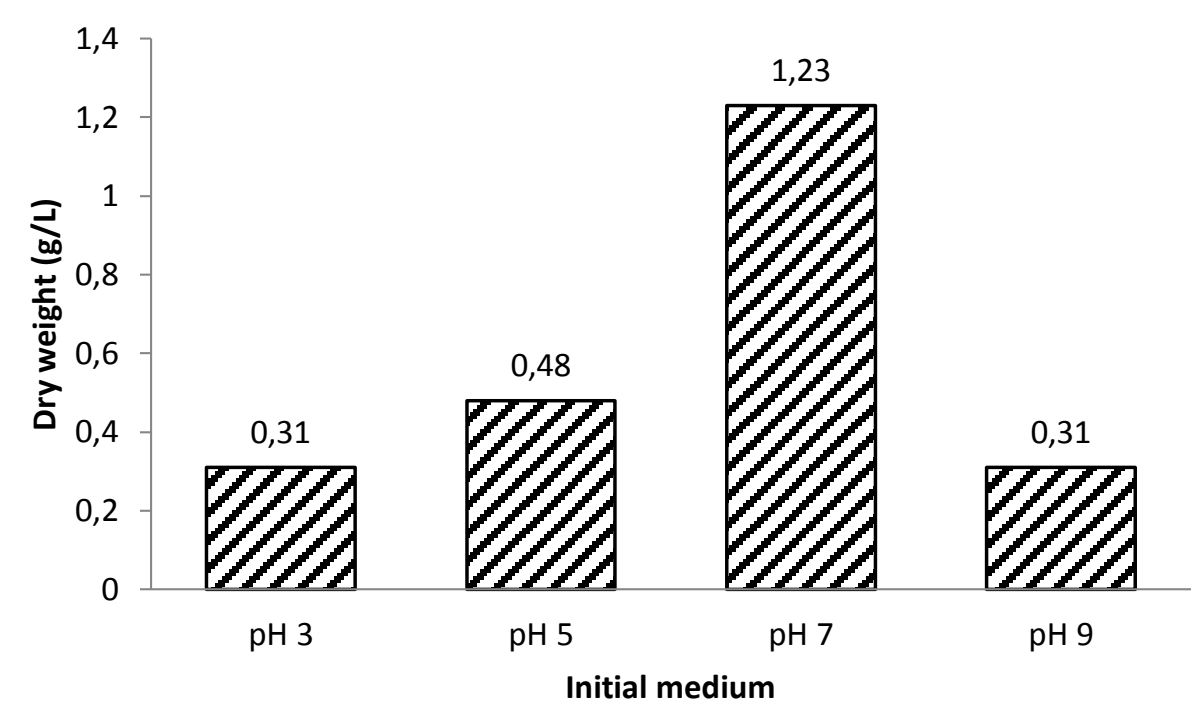

Fig. 4 The average value of isolate number 2 cell dry weight at different $\mathrm{pH}$ treatment

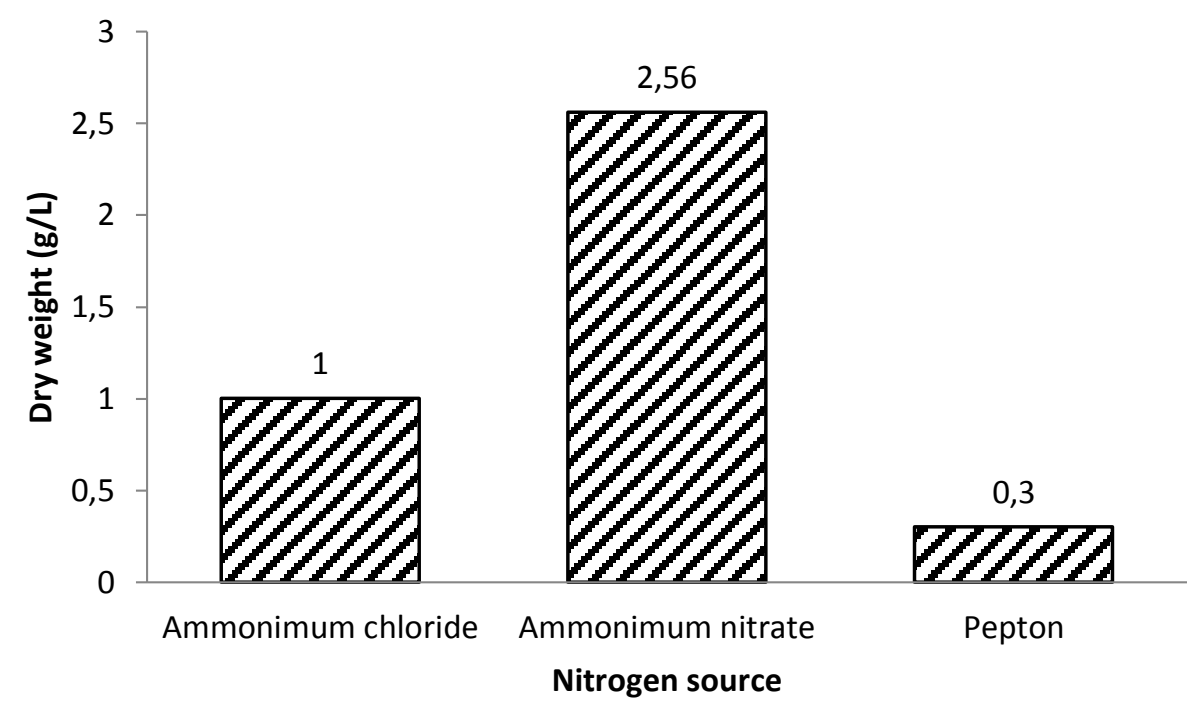

Fig. 5. The average of cell dry weight of isolate number 2 at different source of nitrogen

Production of red pigment from isolate 2 at different source of Nitrogen

The absorbance value indicated the concentration of red pigment. If it was high, then red pigment concentration was also high. The highest average absorbance value of red pigment product was reached at $\mathrm{pH} 7$ (0.81). At $\mathrm{pH} 3$ and 5, the average absorbance value of red pigment product were 0.14 and 0.19 , respectively. The lowest average absorbance value of red pigment product was 0.04 at $\mathrm{pH}$ 9. The average absorbance value of red pigment products is shown in Fig. 6A. Rashmi and Padmavathi (2011) stated that acidic $\mathrm{pH}$ affected physiology, conidia development and synthesis of red pigment. The $\mathrm{pH}$ between 3 and 5 increased the conidia production but it reduced the red pigment production. The result of analysis of 
variance $(p \leq 0.05)$ showed that difference $\mathrm{pH}$ significantly affected the red pigment production of isolate number 2 .

The highest average absorbance value of red pigment product from the isolate was 0.82 by the addition of ammonium chloride. The treatment with ammonium nitrate had the average of absorbance of 0.53 . The lowest red pigment product was 0.49 , obtained by the addition of the peptone. The different of nitrogen source affected highly significant towards the production of red pigment from the isolate $(p<0.05)$. Timotius (2004) suggested that the source of nitrogen use affected the growth and pigment production. $\mathrm{NaNO}_{3}$ and $\mathrm{NH}_{4} \mathrm{NO}_{3}$ cannot support the production of pigment adequately. The best source of nitrogen was $\mathrm{NH}_{4} \mathrm{Cl}$ because it could increase the cell and form orange yellowish pigment. The average production of red pigment with different source of nitrogen can be seen in Fig. 6B.

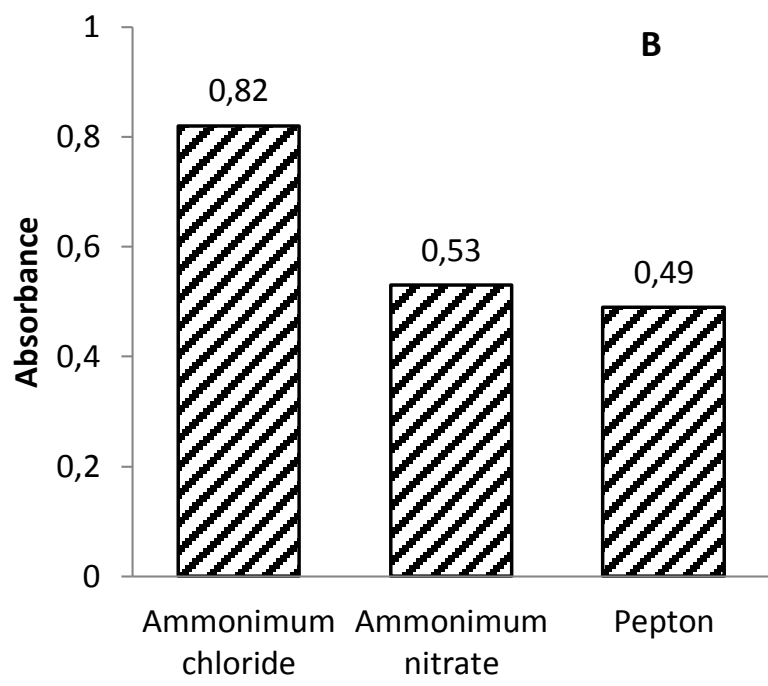

Nitrogen source
Initial medium

A

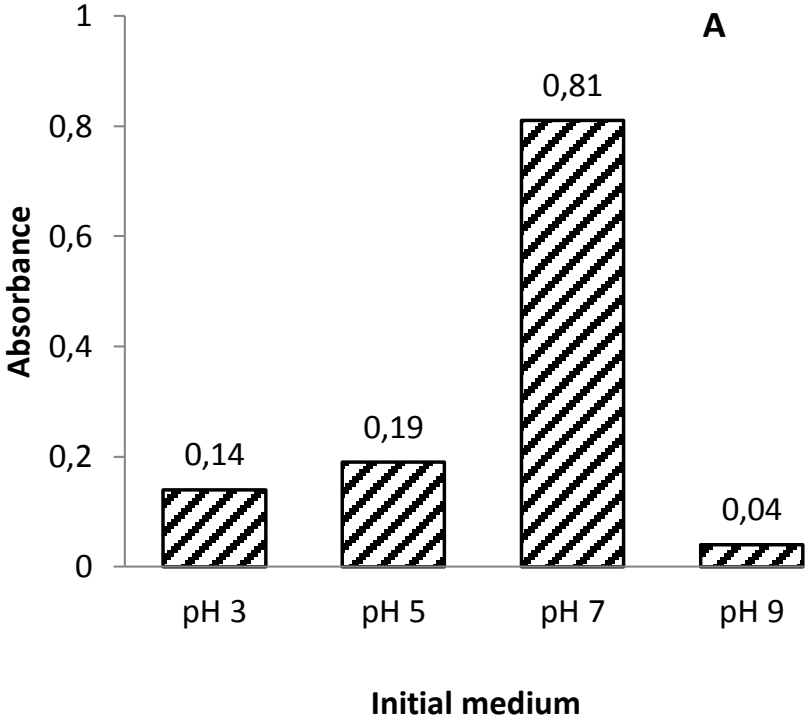

Fig. 6. The average value of red pigment production of isolate number 2 at different $\mathrm{pH}(\mathbf{A})$ and different nitrogen source $(\mathbf{B})$

Some researches stated that the concentration of red pigment increased during fermentation time, then further decreased or steady after reaching the optimum. One of the factors that caused a decrease in the pigment production was the depletion of nutrition for Monascus. Therefore, there was a changing in pigment and reduction of the intracellular and extracellular pigment production.

\section{Conclusions}

Isolation of fungi from angkak obtained 9 isolates. One isolate showed the reddest colony, which was isolate number 2 . The optimum growth of isolate number 2 was at $\mathrm{pH} 7$ and the source of nitrogen was ammonium nitrate. But the optimum pigment production was at $\mathrm{pH} 7$ and the source of nitrogen was ammonium chloride. 


\section{Acknowledgement}

The authors thank Dr. Anto Budiharjo, M. Biotech. for supporting the manuscript preparation.

\section{References}

Babitha, S., Soccol, C.R. and Pandey, A. 2007. Solid-state fermentation for the production of Monascus pigments from jackfruit seed. Biores. Technol. 98:15541560.

Durakh-Velioğlu, S., Boyaci I.H., Simsek O. and Gümüs T. 2013. Optimizing $a$ submerged Monascus cultivation for production of red pigment with bug damaged wheat using artificial neural networks. Food Sci. Biotechnol. 22(6):1639-1648.

Kaur, B, Chakraborty, D. and Kaur, H. 2009. Production and evaluation of physicochemical properties of red pigment from Monascus purpureus MTCC 410. The Int. J. of Microbiology. 7(1):1-6.

Lee, C. H., Lee, C. L. and Pan, T.M. 2010. A 90D toxicity study of Monascus fermented products including high citrinin level. Journal of Science Food and Agricultural 75 (2):91-97.
Mamucod, H.H., Dizon, E.I. and Romero, M.V. 2014. Health-promoting properties and safety of angkak (red mold rice) sold in Nueva Ecija, Philippines. Asia Life Sci. 23 (2):371-383.

Panda, B.P., S. Javed, and M. Ali. 2009. Engineering rice based medium for production of lovastatin with Monascus species. Czech J. Food Sci. 27:352-360.

Priatni, S., Damayanti S., Saraswaty V., Ratnaningrum D., and Singgih M. 2014. The utilization of solid substrates on Monascus fermentation for anticholesterol agent production. Proc. Chem. 9:34-39.

Rashmi, D. And Padmavathi T. 2011. Monascus purpureus A potential source for natural pigment production. J. Microbial. Biotechnol. 1(4):164-174.

Rashmi, D. and Padmavathi T. 2013. Exploring Monascus sanguineus as a potential natural source for pigment production. Int. Res. J. Biological Sci. 2(5):59-67.

Timotius, K. H. 2004. Produksi pigmen angkak oleh Monascus. Jurnal Teknologi Dan Industri Pangan. 15(1):79-86.

Ungureanu, C. 2012. Antibacterial and antifungal activity of red rice obtained from Monascus purpureus. J. of Biopharmacy. 48(1):885-894 